\title{
A Rigid-Flexible Protecting Film with Surface Pits Structure for Dendrite-Free and High-Performance Lithium Metal Anode
}

Di Yang ${ }^{\dagger}$, Jian Lił, Fan Yangll, Jun Lill, Li He', Hainan Zhao ${ }^{\dagger}$, Luyao Wei†, Yizhan Wang ${ }^{\dagger}$, , Xudong Wangll, Yingjin Weit,\#,*

† Key Laboratory of Physics and Technology for Advanced Batteries (Ministry of Education), Jilin Engineering Laboratory of New Energy Materials and Technology, College of Physics, Jilin University, Changchun 130012, China,

\# State Key Laboratory of Supramolecular Structure and Materials, College of Chemistry, Jilin University, Changchun 130012, China

/ Department of Materials Science and Engineering, University of Wisconsin-Madison, 1509 University Avenue, Madison, WI 53706, United States

\# State Key Laboratory of Inorganic Synthesis \& Preparative Chemistry, College of Chemistry, Jilin University, Changchun 130012, China

*Corresponding authors: yiwei@jlu.edu.cn (Y. Wei); wangyizhan@jlu.edu.cn (Y. Wang) 


\section{Experimental section}

Preparation of the SPF film. Before the experiments, all the granular materials were dried in a vacuum oven at $60{ }^{\circ} \mathrm{C}$. Firstly, $0.016 \mathrm{~mol} \mathrm{Al}_{2} \mathrm{O}_{3}$ (Aladdin) and $0.064{\mathrm{~mol} \mathrm{LiNO}_{3}}$ (Aladdin) powder were grounded in a mortar for $30 \mathrm{~min}$. Subsequently, the mixed powder and $6.0 \mathrm{~g}$ poly(vinylidene fluoride-co-hexafluoropropylene) (PVDF-HFP, Aldrich) were added into $30 \mathrm{~mL}$ acetone, and then stirred at $50^{\circ} \mathrm{C}$ for $24 \mathrm{~h}$ to obtain a precursor solution. After the stirring was completed, the precursor solution was spin-coated onto a square glass plate at $2000 \mathrm{rpm}$ for $60 \mathrm{sec}$ to obtain a thin film. The spin coating was carried out in a drying room equipped with a dehumidifier to keep the humidity constant at $\sim 30 \%$. Subsequently, the composite film was transferred into a $60^{\circ} \mathrm{C}$ vacuum oven. After $6 \mathrm{~h}$ of drying, the film was peeled off from the glass plate to obtain the SPF film.

Preparation of the SPF@Li. The prepared SPF film was transferred into a glove box in which $\mathrm{O}_{2}$ and $\mathrm{H}_{2} \mathrm{O}$ contents were controlled below $0.1 \mathrm{ppm}$. The SPF film was spread on a lithium metal sheet and then stainless steel cylindrical pestle was used to roll it repeatedly. Due to the excellent flexibility of SPF and softness of the lithium metal, the two can be in good contact with each other. After that, it was pressed with a circular die to obtain anSPF@Li metal anode.SPF@Cu substrate was obtained by the same method.

Structural and morphological characterizations. The morphological properties of the samples were studied by using a JSM-7900F JEOL scanning electron microscopy (SEM) with operation voltage of $5.0 \mathrm{kV}$. X-ray diffraction (XRD) was studied on a Bruker AXS D8 diffractometer with $\mathrm{Cu}$ Ka radiation $(\lambda=1.5406 \AA$ ). Atomic force microscopy (AFM) was performed on a Bruker Multimode-8 microscopy to get the surface morphology and the force-distance curve of the samples. The Young's modulus of the samples was fitted by the NanoScope Analysis-2.1 Program. X-ray photoelectron spectroscopy (XPS) was conducted on a VG scientific ESCALAB 250 spectrometer. The porosity of the SPF was calculated by measuring the mass of electrolyte absorbed by the SPF. Electrolyte was incrementally added on the SPF, and the addition stopped until the liquid cannot be adsorbed. Filter paper was used to remove excess liquid on the surface, and the weight of SPF before and after electrolyte absorption was recorded. For all testing of lithium metal electrodes, the cells were disassembled in an Ar-filled glove box and then sealed in an Ar-filled sample container.

Electrochemical experiments. All electrochemical experiments were performed 
using CR2032 coin cells assembled in an Ar-filled glove box with $\mathrm{O}_{2}$ and $\mathrm{H}_{2} \mathrm{O}$ contents below $0.1 \mathrm{ppm}$. A LAND-2100 automatic battery tester was used for charge-discharge cycling testing. Electrochemical impedance spectroscopy (EIS) was performed on a Biologic VSP multichannel electrochemical workstation using an ac voltage of $5 \mathrm{mV}$ in the frequency range from $1 \mathrm{MHz}$ to $1 \mathrm{mHz}$. The carbonate-based electrolyte was $1.0 \mathrm{M} \mathrm{LiPF} 6$ in ethylene carbonate (EC)/diethyl carbonate (DEC), 1:1 by volume ratio. The ether-based electrolyte was 1.0 M LiTFSI in 1, 3-dioxolane (DOL)/1, 2-dimethoxyethane (DME), 1:1 by volume ratio with $2.0 \mathrm{wt} \% \mathrm{LiNO}_{3}$ additive. For Coulombic efficiency tests, a $\mathrm{Cu}$ or SPFprotected $\mathrm{Cu}$ (SPF@Cu) substrate was paired with lithium foil. The cells were first activated in 0-1.0 V (vs. $\mathrm{Li}^{+} / \mathrm{Li}$ ) for 5 cycles, then discharged at $1.0 \mathrm{~mA} \cdot \mathrm{cm}^{-2}$ to deposit a fixed amount of lithium on the working electrode, and stripped lithium until the charging voltage reached $1.0 \mathrm{~V}$ (vs. $\mathrm{Li}^{+} / \mathrm{Li}$ ). Ether-based electrolyte was used in the Coulombic efficiency test cells. For symmetrical cell tests, both the cathode and anode were used bare lithium or SPF@Li electrodes. Different current densities and areal capacities were used for galvanostatic cycling. For SEM morphology testing, Li||Cu or Li||SPF@Cu cells were assembled. A current density of $1.0 \mathrm{~mA} \mathrm{~cm}^{-2}$ was used as a galvanostatic discharge for electrodeposition on the Cu or SPF@Cu substrate. Different deposition capacities were obtained by controlling the discharge time. Ionic conductivity was tested in a configuration of stainless steel || SPF \& electrolyte || separator \& electrolyte || stainless steel at room temperature. The ionic conductivity was calculated using the equation $\sigma=$ $\mathrm{L} / \mathrm{R}_{s} \cdot \mathrm{S}$, where $\mathrm{L}$ represents the thickness of the separator and SPF film, Rs represents the bulk resistance, $\mathrm{S}$ is the area of the stainless steel. The $\mathrm{Li}^{+}$transference number $\left(\mathrm{t}_{+}\right)$was measured by Li||electrolyte||Li symmetric cells and $t_{+}$was determined by the following equation:

$$
t_{+}=\frac{I_{S}\left(\triangle V-I_{0} R_{0}\right)}{I_{0}\left(\triangle V-I_{S} R_{S}\right)}
$$

where $\Delta V$ is the constant polarization voltage applied $(10 \mathrm{mV}), \mathrm{I}_{0}$ and $\mathrm{R}_{0}$ are the initial current and resistance, respectively, $\mathrm{I}_{s}$ and $\mathrm{R}_{\mathrm{s}}$ are the steady state current and resistance. The full cells were assembled using the SPF@Li or bare lithium foil as the anode, Celgard 2400 as separator, and LFP $\left(\sim 2 \mathrm{~mA} \cdot \mathrm{h} \cdot \mathrm{cm}^{-2}\right)$ or $\mathrm{S}\left(\sim 1 \mathrm{mg} \cdot \mathrm{cm}^{-2}\right)$ as the cathode. The thickness of the anode was controlled by the degree of rolling pressure, and the N/P ratio of the full cell was $\sim 4$. To assemble "unflooded electrolyte" cells, the SPF@Li anode was first immersed in the electrolyte and matched with the commercial LFP cathode. No extra 
electrolyte was added during the cell assembly process. Each Li || LFP cell contained around $\sim 10.5 \mu \mathrm{L} \cdot \mathrm{mA} \mathrm{h}^{-1}$ electrolyte of cathode capacity. The cells were galvanostatically cycled in the voltage window of 2.5-4.2 V (LFP) and 1.7-2.8 V (S).

Multiphysics simulation. The electric field and stress simulation were conducted by the commercial FEA software ANSYS 19.2 Version. In the electric field simulation, SPF was placed on the surface of lithium metal. For stress simulation, the SPF and natural SEI layer were fixed above the triangular dendrites to simulate the stress. The elastic modulus of lithium metal, natural SEI and SPF was set to $4.8 \mathrm{GPa}, 150 \mathrm{MPa}$ and $7.0 \mathrm{GPa}$, respectively. These simplifications can offer fundamental comprehension in ideal systems, though it cannot fully reflect the real circumstance. 


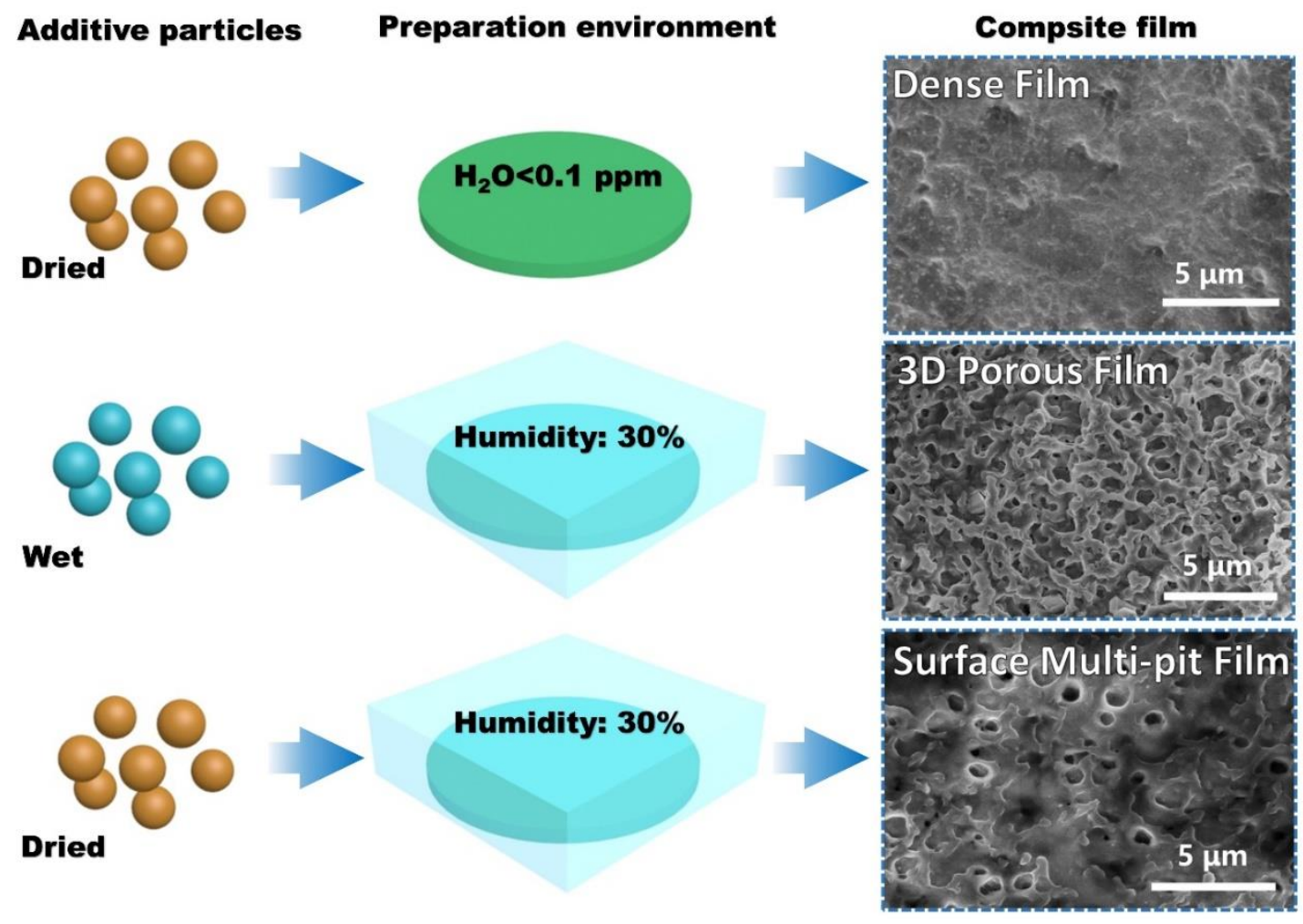

Figure S1. Synthetic schematic diagram and top-view SEM images of the composite films with different morphologies.

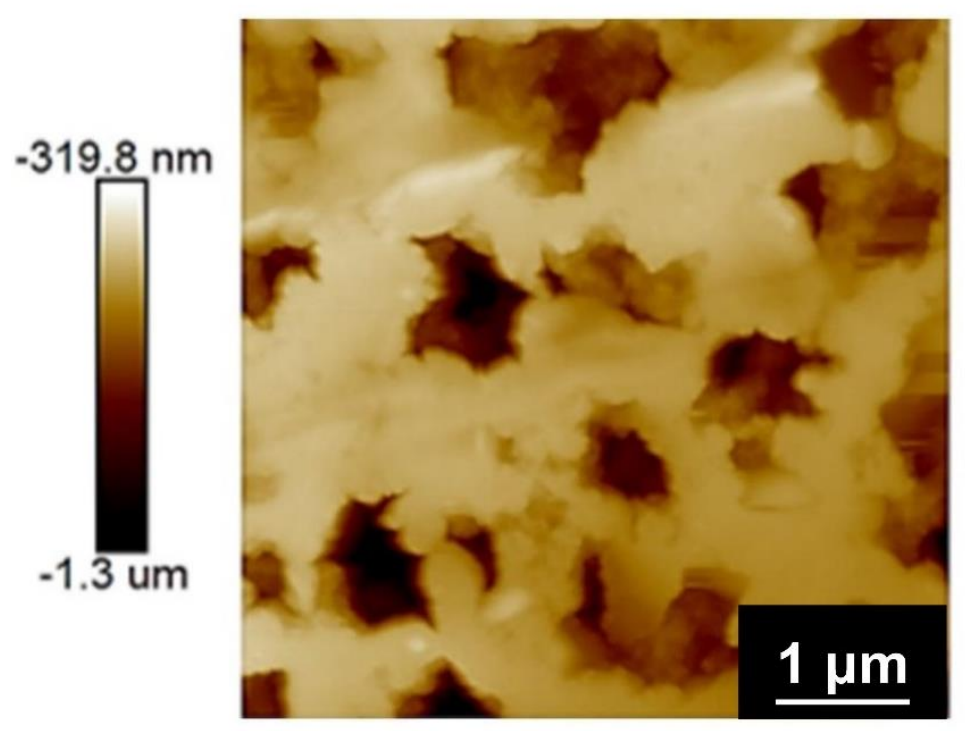

Figure S2. Top view AFM image of the SPF film. 

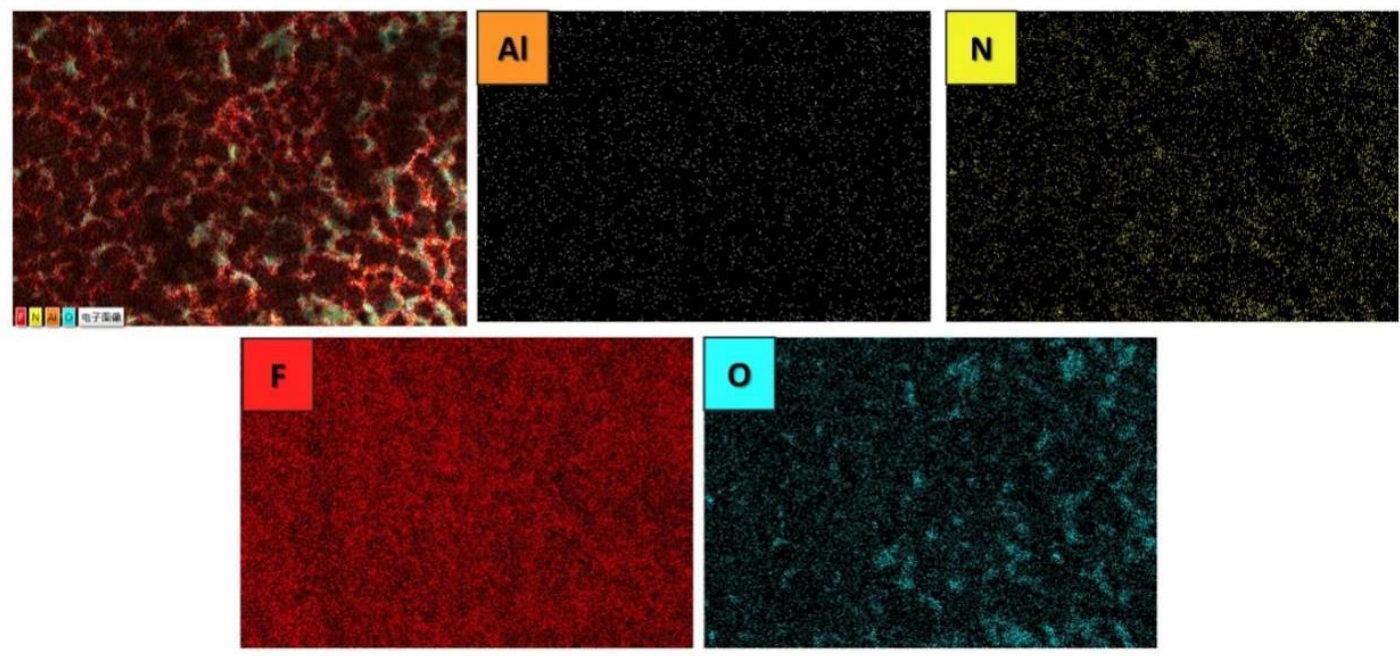

Figure S3. The EDS mapping images of the SPF film.
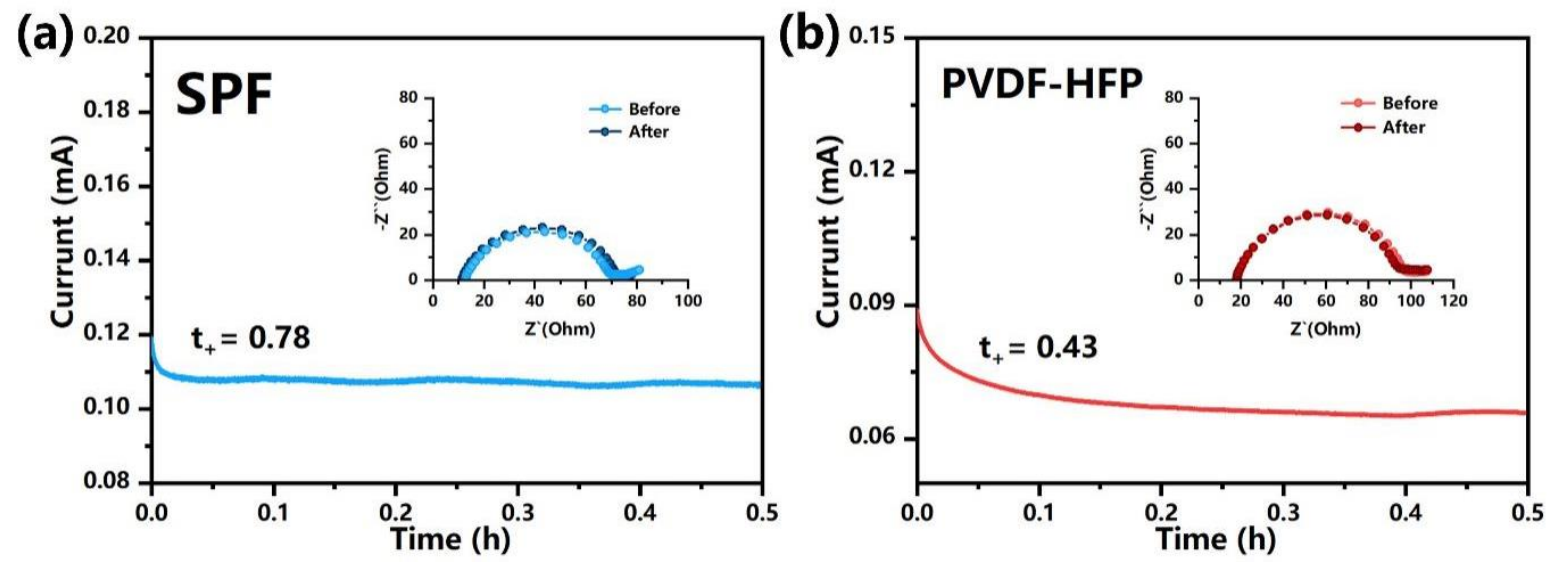

Figure S4. Current-time plots of (a) SPF, (b) PVDF-HFP in symmetric cells at the $10 \mathrm{mV}$ constant potential. Inserts are the impedance spectra before and after polarization.
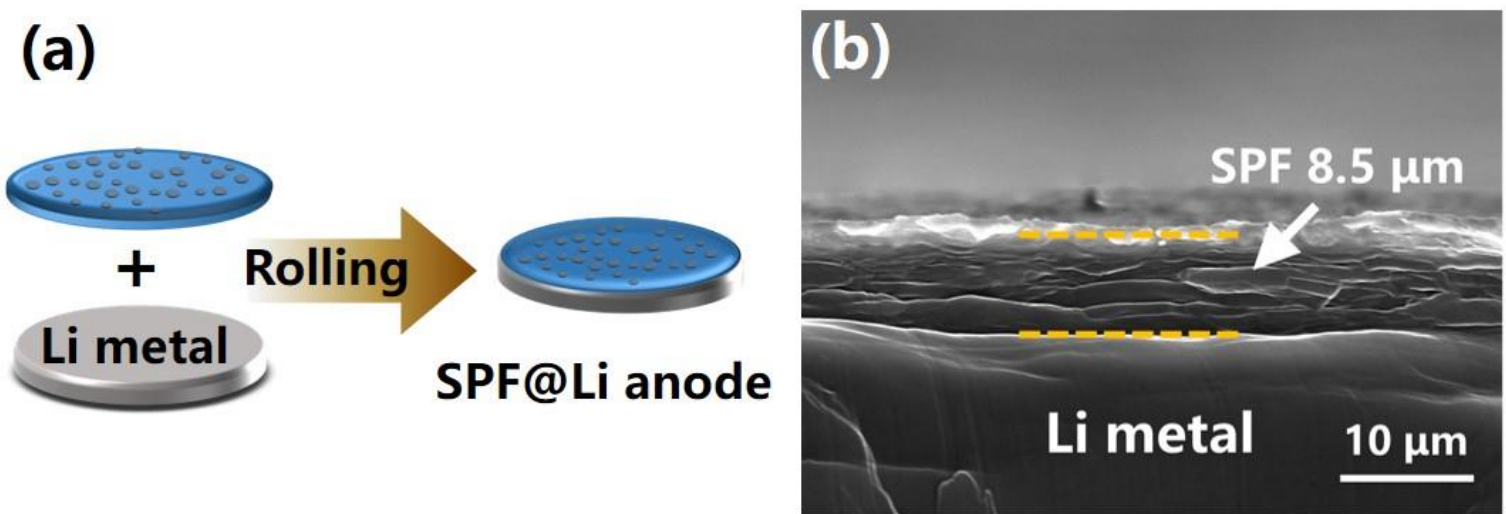

Figure S5. (a) Synthetic schematic diagram and (b) Cross-sectional SEM image of the SPF@Li anode; 

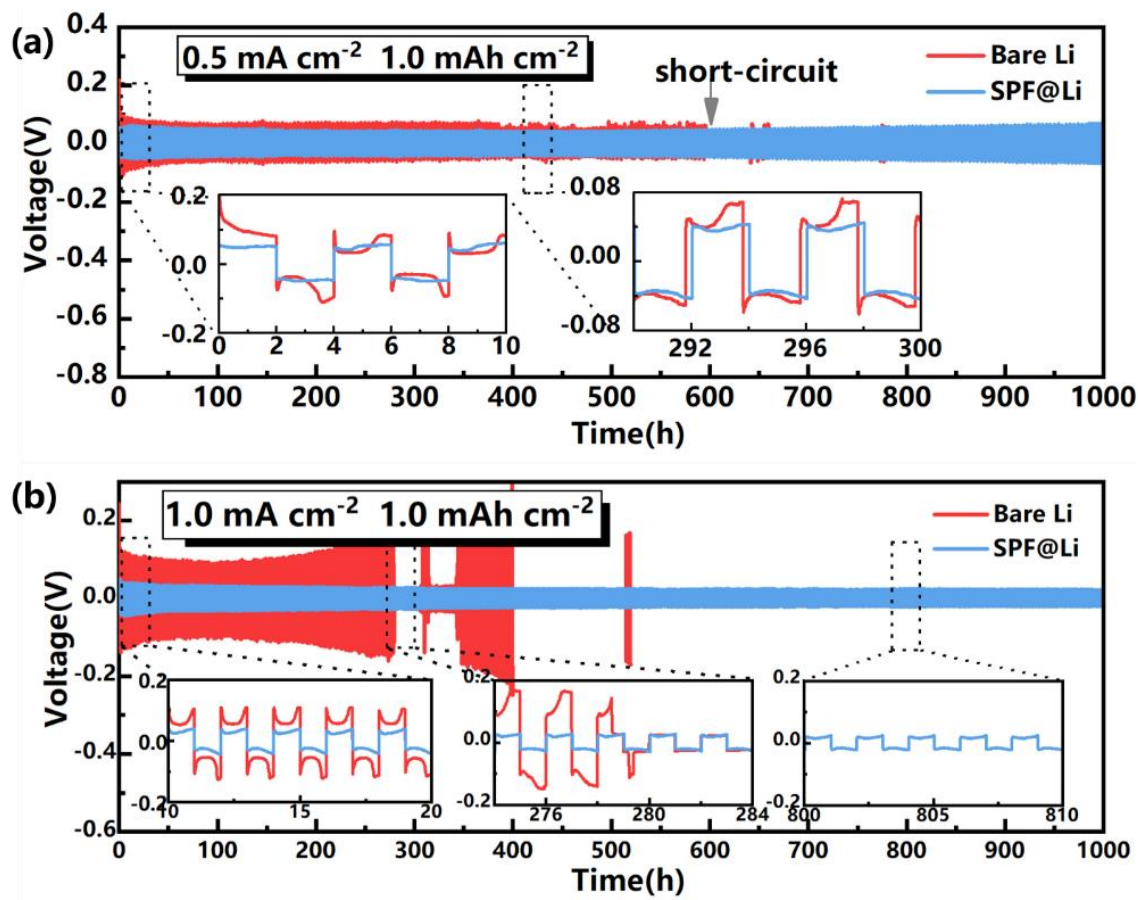

Figure S6. Galvanostatic cycling of Li || Li cells in carbonate electrolyte at (a) 0.5, and (b) $1.0 \mathrm{~mA} \cdot \mathrm{cm}^{-2}$ current density in carbonate electrolyte. The area capacity is fixed at 1.0 $\mathrm{mA} \cdot \mathrm{h} \cdot \mathrm{cm}^{-2}$.

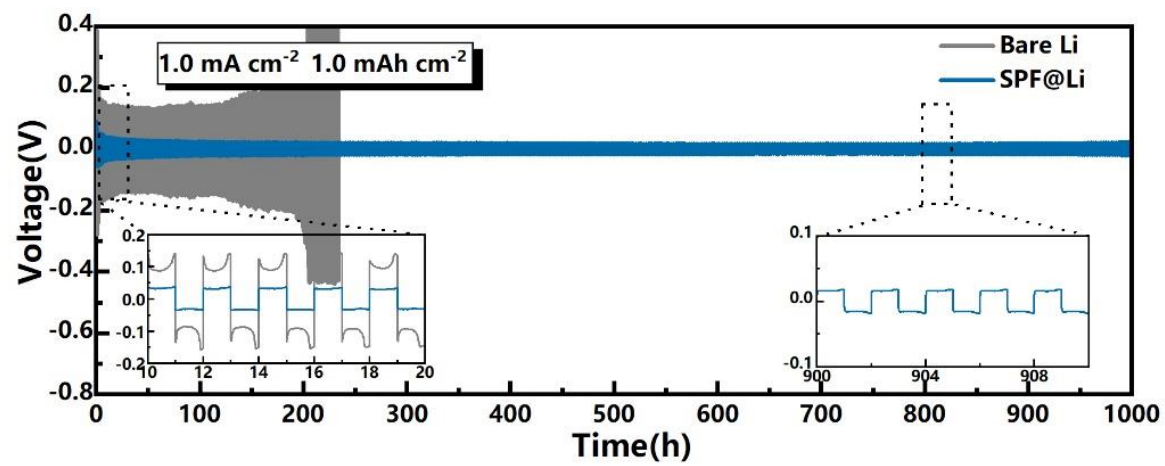

Figure S7. Galvanostatic cycling of $\mathrm{Li} \| \mathrm{Li}$ cells in ether electrolyte at $1.0 \mathrm{~mA} \cdot \mathrm{cm}^{-2}$ current density in ether electrolyte. The area capacity is fixed at $1.0 \mathrm{~mA} \cdot \mathrm{h} \cdot \mathrm{cm}^{-2}$.

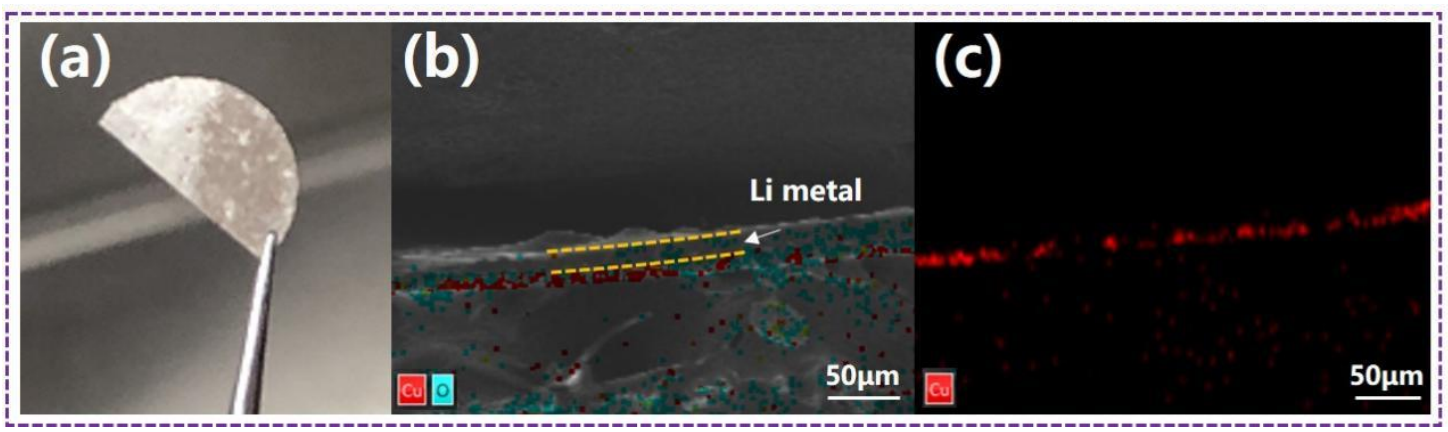


Figure S8. The morphology of the SPF-protected $\mathrm{Cu}$ after the deposition of Li with a capacity of $4 \mathbf{~ m A} \cdot \mathbf{h} \cdot \mathbf{c m}^{-2}$. (a) Photograph of the $\mathrm{Cu}$ surface after the SPF was removed, it can be clearly seen that Li metal was deposited on the Cu substrate; (b) Cross-sectional SEM image of the structure after deposition. The mapping test (c) confirmed that Li metal was deposited on the $\mathrm{Cu}$ foil.
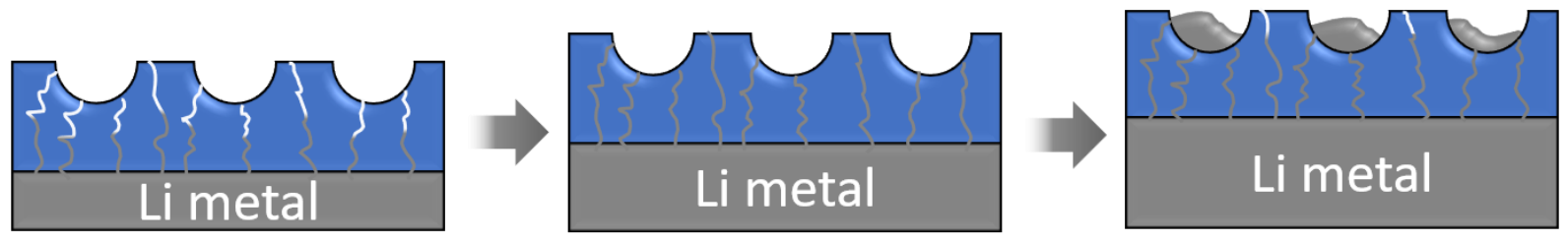

Figure S9. Schematic diagram of lithium deposited in the surface pits of SPF.
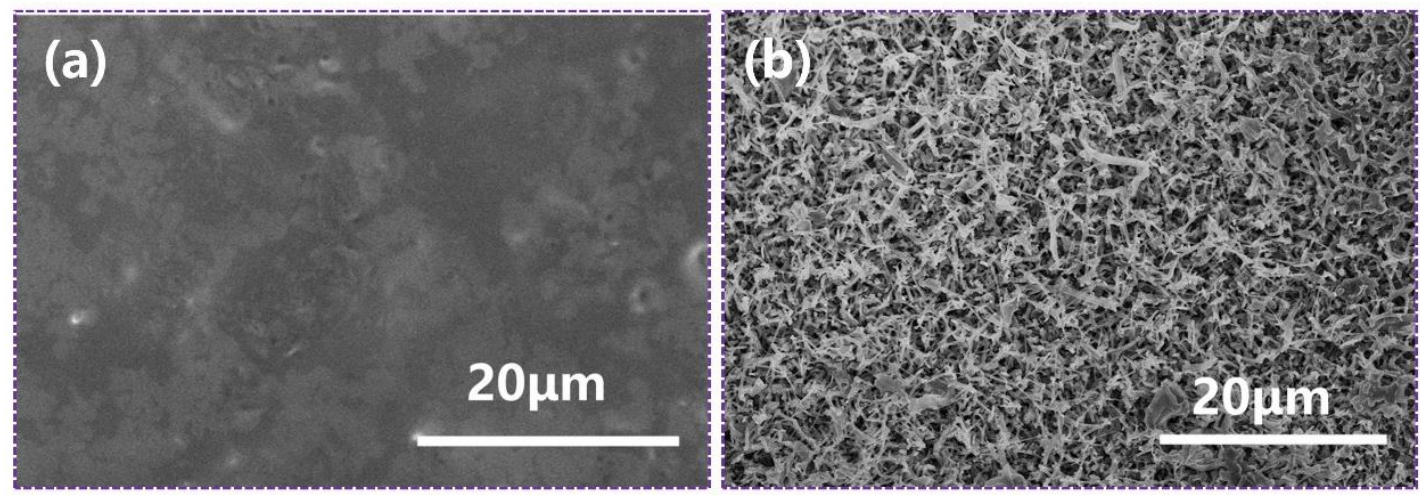

Figure S10. Top-view SEM images of Li deposition on the (a) SPF-protected electrode and (b) bare electrode after plating capacity of $1.0 \mathrm{~mA} \cdot \mathrm{h} \cdot \mathrm{cm}^{-2}$ at $10.0 \mathrm{~mA} \cdot \mathrm{cm}^{-2}$.
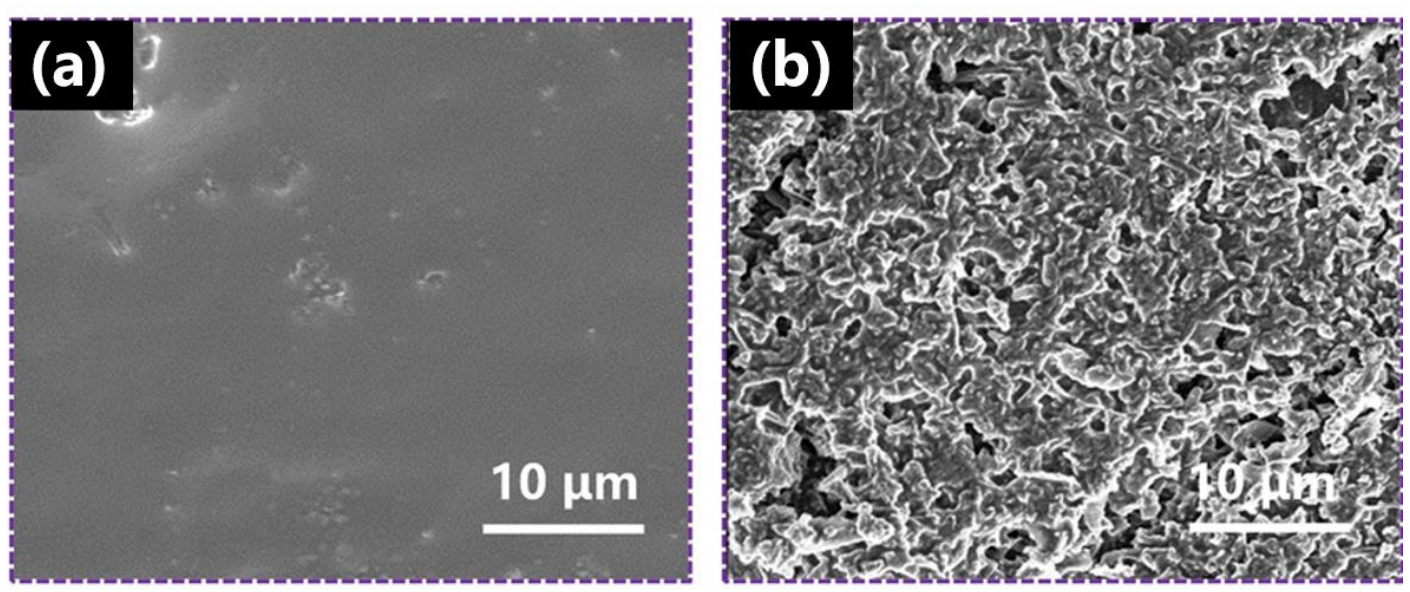
Figure S11. Top-view SEM images of (a) SPF@Li and (b) bare Li after 100 cycles.

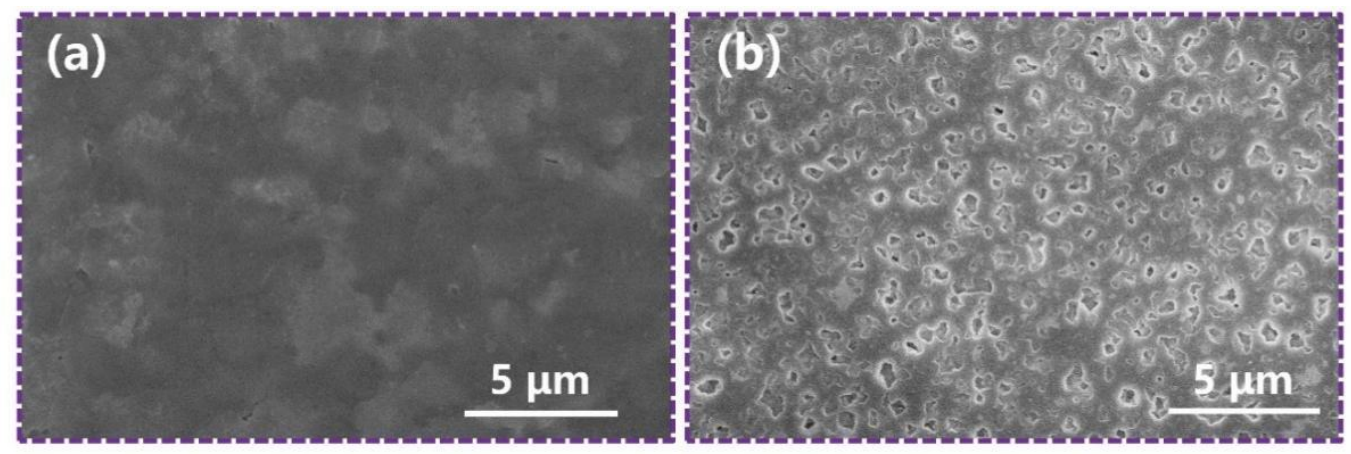

Figure S12. Top-view SEM images of the SPF film after 100 cycles when Li was (a) deposited and (b) stripped.

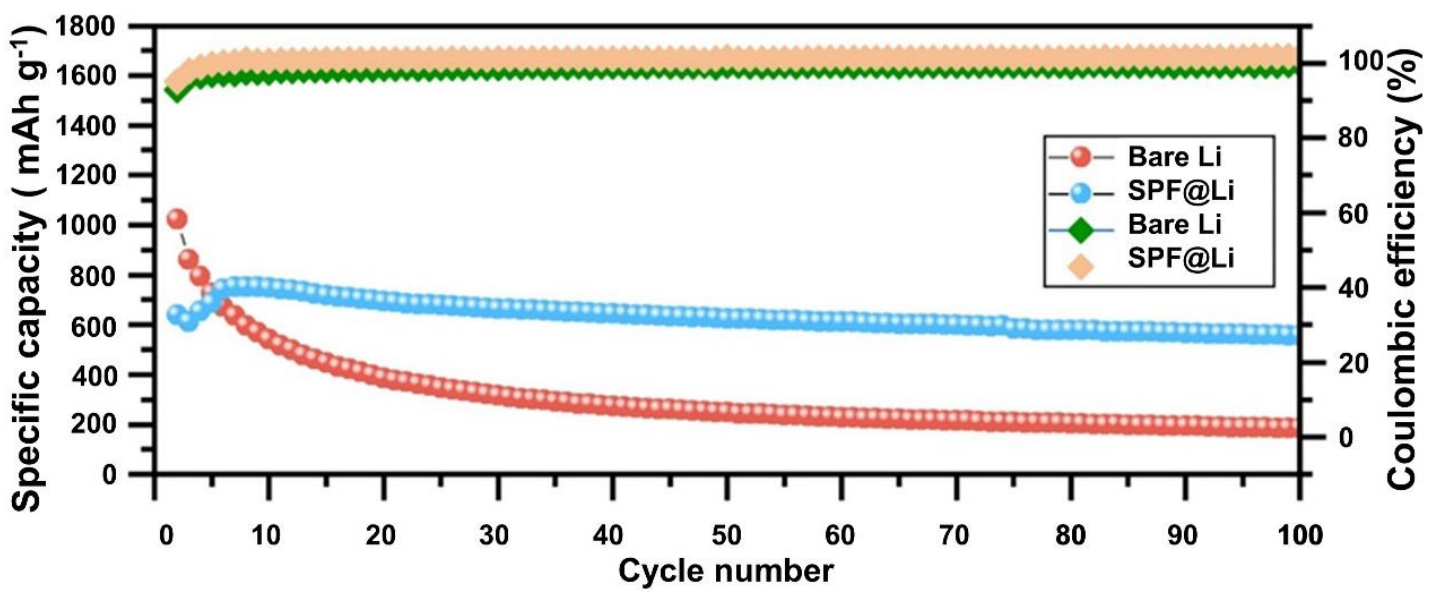

Figure S13. Electrochemical performance of Li \| S full cells 
(a)
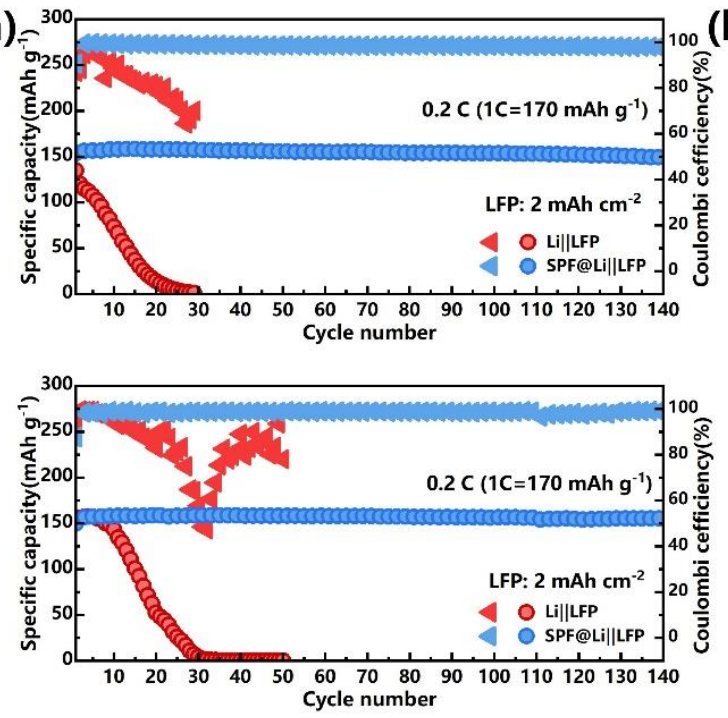

(b) $=$
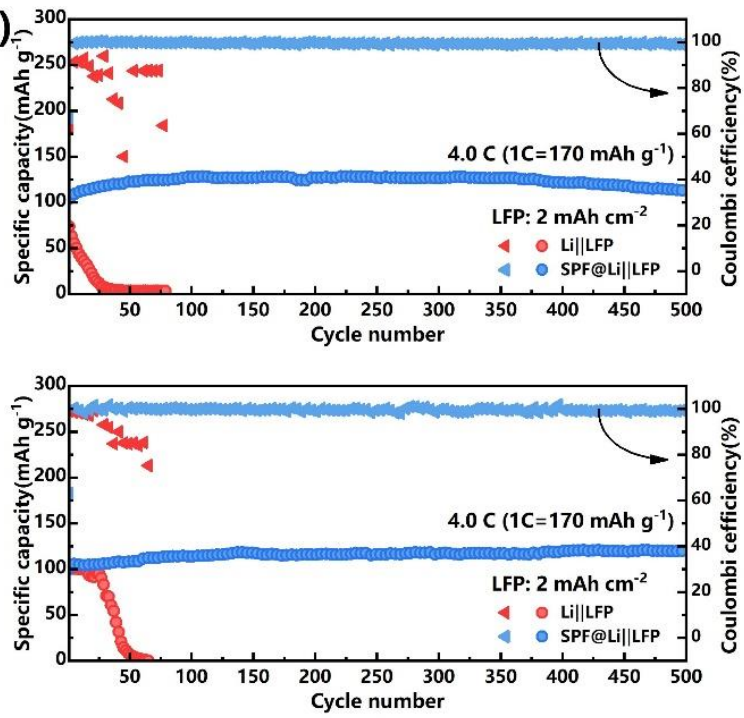

Figure S14. Repeated experiment of SPF@Li||LFP and Li||LFP cells at (a) $0.2 \mathrm{C}$ and (b) $4.0 \mathrm{C}$. 
Table S1. Ionic conductivity of the pure electrolyte and different protective layers swelled in electrolyte.

\begin{tabular}{|c|c|c|}
\hline & $\begin{array}{c}\text { Bulk resistance } \\
\left(\mathbf{R s}, \mathbf{~ O h m ~} \mathbf{~ m}^{-\mathbf{2}} \mathbf{)}\right.\end{array}$ & $\begin{array}{c}\text { Ionic conductivity } \\
\mathbf{( S ~ c m} \mathbf{- 1})\end{array}$ \\
\hline Pure electrolyte & 2.74 & $2.89 \times 10^{-3}$ \\
\hline PVDF-HFP swelled in electrolyte & 23.31 & $3.53 \times 10^{-4}$ \\
\hline SPF swelled in electrolyte & 10.69 & $7.75 \times 10^{-4}$ \\
\hline
\end{tabular}

*Pure electrolyte refers to $1.0 \mathrm{M} \mathrm{LiPF}_{6}$ in EC/DEC, 1:1 by volume ratio

Table S2. The current and resistance obtained before/after polarization for the calculation of $\mathrm{Li}^{+}$transference number.

\begin{tabular}{c|c|c|c|c|c}
\hline & $\mathrm{I}_{0}(\mathrm{~mA})$ & $\mathrm{I}_{\mathrm{s}}(\mathrm{mA})$ & $\mathrm{R}_{0}(\Omega)$ & $\mathrm{R}_{\mathrm{s}}(\Omega)$ & $t_{+}$ \\
\hline PVDF-HFP & 0.089 & 0.066 & 80.53 & 77.42 & 0.43 \\
\hline SPF & 0.119 & 0.106 & 59.38 & 62.65 & 0.78 \\
\hline
\end{tabular}


Table S3. Comparison of cycle performance in $\mathrm{Li} \| \mathrm{Li}$ symmetrical cells with other artificial SEI at different current densities (deposition capacity was fixed at $1.0 \mathrm{~mA} \cdot \mathrm{h} \cdot \mathrm{cm}^{-}$ $\left.{ }^{2}\right)$.

\begin{tabular}{|c|c|c|c|}
\hline SEI strategy & Electrolyte & Current density & Cycle time \\
\hline \multirow{2}{*}{$\begin{array}{c}\mathrm{LiF} \\
(\text { Adv Funct Mater 28, 1705838, 2018) }\end{array}$} & \multirow{2}{*}{$\begin{array}{c}1 \mathrm{M} \text { LiTFSI in } \\
\text { DOL/DME }(1: 1)\end{array}$} & $2.0 \mathrm{~mA} \cdot \mathrm{cm}^{-2}$ & $200 \mathrm{~h}$ \\
\hline & & $5.0 \mathrm{~mA} \cdot \mathrm{cm}^{-2}$ & $100 \mathrm{~h}$ \\
\hline \multirow{3}{*}{$\begin{array}{l}\text { Graphite fluoride-LiF } \\
\text { (Nat Commun 10, 900, 2019) }\end{array}$} & \multirow{3}{*}{$\begin{array}{l}1 \text { M LiPF6 in } \\
\text { EC/DEC }(1: 1)\end{array}$} & $1.0 \mathrm{~mA} \cdot \mathrm{cm}^{-2}$ & $208 \mathrm{~h}$ \\
\hline & & $5.0 \mathrm{~mA} \cdot \mathrm{cm}^{-2}$ & $56 \mathrm{~h}$ \\
\hline & & $10.0 \mathrm{~mA} \cdot \mathrm{cm}^{-2}$ & $33 \mathrm{~h}$ \\
\hline \multirow{2}{*}{$\begin{array}{c}\mathrm{Li}_{X} \mathrm{Si} \text { alloy } \\
(\text { Adv Energy Mater 10, 1092343, } \\
\text { 2020) }\end{array}$} & \multirow{2}{*}{$\begin{array}{c}1 \mathrm{M} \text { LiTFSI in } \\
\text { DOL/DME }(1: 1)\end{array}$} & $1.0 \mathrm{~mA} \cdot \mathrm{cm}^{-2}$ & $500 \mathrm{~h}$ \\
\hline & & $10.0 \mathrm{~mA} \cdot \mathrm{cm}^{-2}$ & $120 \mathrm{~h}$ \\
\hline \multirow{2}{*}{$\begin{array}{c}\text { Li alkoxides } \\
\text { (Energy Storage Mater } \mathbf{2 4}, 618,2020 \text { ) }\end{array}$} & \multirow{2}{*}{$\begin{array}{c}1 \mathrm{M} \mathrm{LiPF}_{6} \text { in EC/ } \\
\text { DEC/DMC } \\
(1: 1: 1)\end{array}$} & $0.5 \mathrm{~mA} \cdot \mathrm{cm}^{-2}$ & $400 \mathrm{~h}$ \\
\hline & & $2.0 \mathrm{~mA} \cdot \mathrm{cm}^{-2}$ & $120 \mathrm{~h}$ \\
\hline $\begin{array}{c}\text { Hybrid polyurea } \\
\text { (Adv Energy Mater 10, 2001139, } \\
\text { 2020) } \\
\end{array}$ & $\begin{array}{c}\mathrm{M} \mathrm{LiPF}_{6} \text { in EC/ } \\
\text { DEC/DMC } \\
(1: 1: 1) \\
\end{array}$ & $5.0 \mathrm{~mA} \cdot \mathrm{cm}^{-2}$ & $80 \mathrm{~h}$ \\
\hline \multirow{2}{*}{$\begin{array}{c}\mathrm{C}_{60} / \mathrm{Mg} \\
\text { (Adv Energy Mater 10, 1903292, } \\
\text { 2019) }\end{array}$} & \multirow{2}{*}{$\begin{array}{c}1 \mathrm{M} \mathrm{LiPF}_{6} \text { in EC/ } \\
\mathrm{DEC} / \mathrm{EMC} \\
(3: 2: 5)\end{array}$} & $1.0 \mathrm{~mA} \cdot \mathrm{cm}^{-2}$ & $550 \mathrm{~h}$ \\
\hline & & $3.0 \mathrm{~mA} \cdot \mathrm{cm}^{-2}$ & $180 \mathrm{~h}$ \\
\hline \multirow{3}{*}{$\begin{array}{c}\text { Li polyacrylic acid } \\
\text { (Angew Chem Int Ed 57, 1505, } \\
\text { 2018) }\end{array}$} & \multirow{3}{*}{$\begin{array}{c}1 \mathrm{M} \mathrm{LiPF}_{6} \text { in EC/ } \\
\text { DEC/DME } \\
(1: 1: 1)\end{array}$} & $0.5 \mathrm{~mA} \cdot \mathrm{cm}^{-2}$ & $700 \mathrm{~h}$ \\
\hline & & $1.0 \mathrm{~mA} \cdot \mathrm{cm}^{-2}$ & $250 \mathrm{~h}$ \\
\hline & & $2.0 \mathrm{~mA} \cdot \mathrm{cm}^{-2}$ & $120 \mathrm{~h}$ \\
\hline $\begin{array}{c}\text { LLZTO/ } \\
\text { Li-Nafion } \\
(\text { Adv Mater } \mathbf{3 1}, \mathrm{e} 1808392,2019) \\
\end{array}$ & $\begin{array}{c}1 \mathrm{M} \text { LiTFSI in } \\
\text { DOL/DME }(1: 1)\end{array}$ & $8.0 \mathrm{~mA} \cdot \mathrm{cm}^{-2}$ & $220 \mathrm{~h}$ \\
\hline \multirow{3}{*}{$\begin{array}{c}\text { Surface fluorination } \\
\text { (JAm Chem Soc 139, 11550, 2017) }\end{array}$} & \multirow{3}{*}{$\begin{array}{l}1 \mathrm{M} \mathrm{LiPF}_{6} \text { in } \\
\text { EC/DEC }(1: 1)\end{array}$} & $1.0 \mathrm{~mA} \cdot \mathrm{cm}^{-2}$ & $600 \mathrm{~h}$ \\
\hline & & $3.0 \mathrm{~mA} \cdot \mathrm{cm}^{-2}$ & $120 \mathrm{~h}$ \\
\hline & & $5.0 \mathrm{~mA} \cdot \mathrm{cm}^{-2}$ & $120 \mathrm{~h}$ \\
\hline \multirow{5}{*}{ This work } & \multirow{3}{*}{$\begin{array}{l}1 M_{\text {MiPF } 6 \text { in }} \\
\text { EC/DEC (1:1) }\end{array}$} & $0.5 \mathrm{~mA} \cdot \mathrm{cm}^{-2}$ & $1000 \mathrm{~h}$ \\
\hline & & $1.0 \mathrm{~mA} \cdot \mathrm{cm}^{-2}$ & $1000 \mathrm{~h}$ \\
\hline & & $10.0 \mathrm{~mA} \cdot \mathrm{cm}^{-2}$ & $1000 \mathrm{~h}$ \\
\hline & \multirow{2}{*}{$\begin{array}{c}1 \text { M LiTFSI in } \\
\text { DOL/DME (1:1) }\end{array}$} & $0.5 \mathrm{~mA} \cdot \mathrm{cm}^{-2}$ & $2800 \mathrm{~h}$ \\
\hline & & $1.0 \mathrm{~mA} \cdot \mathrm{cm}^{-2}$ & $1000 \mathrm{~h}$ \\
\hline
\end{tabular}


Table S4. Electrolyte absorption test for the measurement of SPF porosity. The weight of SPF before and after liquid absorption was recorded as $M_{1}$ and $M_{2}$. The difference $(\triangle M)$ is the quality of the sucked liquid. The inhaled liquid volume was calculated by the formula $V=\triangle M / \rho$, which was approximately the pore volume. The film volume is $4.25 \times 10^{-3} \mathrm{~cm}^{3}$ (thickness: $8.5 \mu \mathrm{m}$, area: $0.5 \mathrm{~cm}^{2}$ ). The surface pit on SPF was treated as a semi-ellipsoid with a major axis of $1 \mu \mathrm{m}$ and a minor axis of $0.5 \mu \mathrm{m}$. The surface depression volume is $1.05 \mu \mathrm{m}^{3}$, which provides $\sim 8 \%$ porosity. Finally, the lithium metal capacity corresponding to the pore volume was calculated. The lithium metal average capacity in the SPF was $\sim 0.58 \pm 0.04 \mathrm{~mA} \cdot \mathrm{h} \cdot \mathrm{cm}^{-2}$.

\begin{tabular}{|c|c|c|c|c|c|c|}
\hline No. & $\begin{array}{c}\mathrm{M}_{1} \\
(\mathrm{mg})\end{array}$ & $\begin{array}{c}\mathrm{M}_{2} \\
(\mathrm{mg})\end{array}$ & $\begin{array}{c}\triangle \mathrm{M} \\
(\mathrm{mg})\end{array}$ & $\begin{array}{c}\mathrm{V} \\
(\mu \mathrm{L})\end{array}$ & Porosity & $\begin{array}{c}\text { Lithium capacity } \\
\mathrm{n}\left(\mathrm{A} \cdot \mathrm{h} \cdot \mathrm{cm}^{-2}\right)\end{array}$ \\
\hline 1 & 2 & 3.7 & 1.7 & 1.42 & $33.33 \%$ & 0.57 \\
\hline 2 & 2.3 & 3.9 & 1.6 & 1.33 & $31.37 \%$ & 0.53 \\
\hline 3 & 2.3 & 4.0 & 1.7 & 1.42 & $33.33 \%$ & 0.57 \\
\hline 4 & 1.9 & 3.5 & 1.6 & 1.33 & $31.37 \%$ & 0.53 \\
\hline 5 & 2.1 & 3.7 & 1.6 & 1.33 & $31.37 \%$ & 0.53 \\
\hline 6 & 2.2 & 3.9 & 1.7 & 1.42 & $33.33 \%$ & 0.57 \\
\hline 7 & 1.9 & 3.9 & 2 & 1.67 & $39.21 \%$ & 0.67 \\
\hline 8 & 1.5 & 3.2 & 1.7 & 1.42 & $33.33 \%$ & 0.57 \\
\hline 9 & 2.1 & 4 & 1.9 & 1.58 & $37.25 \%$ & 0.63 \\
\hline 10 & 2.3 & 4.1 & 1.8 & 1.50 & $35.29 \%$ & 0.60 \\
\hline Average & - & - & - & - & $33.92 \pm 7.73 \%$ & $0.58 \pm 0.04$ \\
\hline
\end{tabular}

